Article

\title{
The Economic Effects of Climate Change Adaptation Measures: Evidence from Miami-Dade County and New York City
}

\author{
Seung Kyum Kim \\ Graduate School of Design, Harvard University, Cambridge, MA 02138, USA; skim1@gsd.harvard.edu
}

Received: 11 January 2020; Accepted: 1 February 2020; Published: 4 February 2020

check for updates

\begin{abstract}
This research examines the economic impact of climate change adaptation measures on the housing markets of two representative coastal cities in the United States located along the Atlantic Ocean. The results shed light on how adaptation measures and investments influence housing values and local real estate markets with respect to their place-based and local forms of implementation. Numerous quantitative approaches, with the use of geospatial data, panel-data hedonic regressions, and difference-in-differences analyses, are used to examine changes in property values associated with climate adaptation measures and the dynamics of risk perception. The results also signal how risk perception and hurricane characteristics are reflected in housing markets, thereby shedding light on the effects of anticipatory and reactive adaptation strategies on property values in these coastal communities. Collectively, the study suggests which adaptation strategies and characteristics can contribute to maximizing both community resilience and economic benefits against the weather extremes caused by climate change.
\end{abstract}

Keywords: climate change adaptation; hurricane characteristics; risk perception; housing price; hedonic pricing; difference-in-differences

\section{Introduction}

As climate change accelerates, extreme meteorological events such as coastal floods and storm surges are occurring more frequently and with greater intensity [1]. According to the National Oceanic and Atmospheric Administration (NOAA), in 2017 alone, Hurricane Harvey caused total damages in the amount of $\$ 125$ billion in the United States (US). In that same year, Hurricane Irma destroyed 25\% of buildings in the Florida Keys. Moreover, the frequency of billion-dollar disaster events in the past five years doubled from the average frequency between 1980 and 2016 [2].

Despite increases in disruptive climatic risks, coastal population density is growing, fueled by the positive effects of coastal amenities [3] and flood insurance subsidies [4], and it is now nearly three times that of the hinterlands over the past half-century [5]. This paradoxical phenomenon-the spatial coexistence of urban growth and risk increase-led to an exponential increase in vulnerability to climate risk.

To alleviate problems caused by this paradox, many coastal cities are allocating a considerable amount of their budgets toward climate change adaptation projects, including planned retreat, nearshore armoring, and ways of enhancing adaptive capacity. Among the strategies that were widely discussed over the last half century, however, retreat and relocation options are seen as highly unfavorable on the basis of the financial burden, legal conflicts, and numerous other socio-cultural issues these strategies require [6]. By contrast, on-site adaptation measures are gaining more popularity, since these allow homeowners to keep coastal amenities and local place identity, whilst curbing potential asset and cultural value degradation due to climate change [7-10]. 
However, the existing literature pays insufficient attention to measuring the economic effects of these on-site climate adaptation measures. This is primarily due to factors such as the unpredictability of the risks in time and space, locally different disaster preparedness capacities, and the subjective nature of climate risk perception [11]. Furthermore, the reactive nature of adaptation projects—climate adaptation decision-making is mostly based on past climate events-prevents evaluating already implemented adaptation projects until the next climate event [12].

Such complexity aside, identifying the economic effects of adaptation measures on real estate markets is necessary, due to the significant share of the housing market in the urban economies, as well as the view of pragmatic economic dimensions concerning existing urban infrastructures. During the past half-century, a severe storm impacted Miami-Dade County (MDC) every two years and New York City (NYC) every five years $[13,14]$. Due to the storm intensity and frequency, Miami-Dade County and New York City spent more than $\$ 326$ million (\$18 per capita per year) and $\$ 1.6$ billion (\$38 per capita per year) for on-site adaptation projects from 2012 to 2016 [15,16]. Thus, the study areas, having high storm occurrences and high climate adaptation budgets, serve as clear subjects for analyzing the effects of adaptation measures.

Using data on 169,958 single-family housing sales (MDC: 79,181 and NYC: 90,777) from July 2009 to May 2018 in these two sites, I employed a hedonic pricing model and difference-in-differences (DID) framework to examine the economic impact of climate change adaptation measures on the housing markets, with risk perception factors and individual storm characteristics.

I found a positive effect of structural elevation and green infrastructure on the value of nearby housing in both regions. Adaptation measures for storm surges provide a particularly strong impact on housing price appreciation. By contrast, properties near public building reinforcement and equipment retrofitting projects, hurricane shelters, or adaptation projects for wind protection show no evidence of such effects. The results, thus, provide quantitative evidence that supports the ongoing debates on the economic efficacy of climate change adaptation measures, contributing to improving the effectiveness of future adaptation policies and urban resilience strategies in coastal areas.

\section{Literature Review}

A number of studies identified the effects of coastal amenities on housing markets. The majority of the literature suggests that property values are positively related by proximity to the coast because of the amenity effects (such as ocean views and accessibility to beaches) and are particularly strong within 500 feet of the coastline [17]. Pompe [18] found that ocean views add approximately $45 \%$ to housing values on Seabrook Island in South Carolina. Similarly, Benson, et al. [19] confirmed that ocean view quality differentiates a sales price premium. Landry and Hindsley [20] found that the influence of beach quality on local property values is significantly positive within 1000 feet. Gopalakrishnan, et al. [21] suggested that beach width is strongly associated with property value increase.

In contrast to the positive impacts of these coastal amenities, risks associated with major storms typically have adverse impacts on housing prices. Bin and Polasky [22] indicated that flood risk decreases market values, and the effect is substantially larger post storm occurrences than prior. Higher flood risk probability is associated with housing price decreases $[23,24]$. Hallstrom and Smith [25] confirmed that risk information without any physical harms decreases housing prices by $19 \%$, which is similar to the effect in areas that have significant storm damages. This is not only because physical damages occurred, but also because of the perceived risk's negative effect on property value [26]. Similarly, Kousky [27] indicated that damaged infrastructure or the stigmatizing of an area as "risk-prone" after a disaster can also influence property values outside of a floodplain.

These adverse impacts of risk probability and information are influenced by human cognitive perspectives. Otto, et al. [28] suggested that a newer risk experience affects individuals' response to future risks by modifying their true risk perception. Meyer, et al. [29] found that perceived risk between before and after a hurricane strikes can be altered by "hindsight." This cognitive tendency leads homeowners to underestimate the actual threats of hurricanes, resulting in a failure of adequate 
storm preparation. Pryce, et al. [30] indicated that risks can be influenced by discounting risk cognition of anticipated future events (myopic tendency about unrealized risk) while forgetting past events over time.

With respect to storm idiosyncrasies, hurricane characteristics can also play a significant role in housing market dynamics. Ewing, et al. [31] discovered that windstorms adversely influence housing prices by $1.5 \%$ to $2 \%$ promptly after the storm events. On the contrary, Meyer, Baker, Broad, Czajkowski and Orlove [29] found that wind speed of hurricanes is overestimated while the flooding is underestimated because the current hurricane warning system (i.e., the Saffir-Simpson Hurricane Scale) largely relies on wind power.

Regardless of the individual storm characteristics, a major storm occurrence can directly affect local market dynamics. Murphy and Strobl [32] indicated that major storms have a positive influence on housing values temporarily because of the shortfall of available housing supply immediately after a hurricane occurrence. Conversely, Beracha and Prati [33] argued that both home sales volumes and prices decline within several months post hurricane and rebound to the prices before the event. Although a large body of literature suggests that the adverse effect of hurricanes on housing prices is generally transitory [34-36], this negative impacts can be prolonged for years depending on local market economies [37,38].

Several hurricane-specific studies also support the market impacts of the major storms. Komarek and Filer [39] found that hurricane Irene (2011) negatively influenced residential real estate markets at a localized level in southeast Virginia, and the effects were differentiated by floodplains (100-year vs. 500-year floodplains). Similarly, Ortega and Taspinar [36] found that properties that were damaged by Sandy in 2012 suffered a significant price drop in NYC by 17-22\% immediately following the hurricane. Properties in a flood hazard zone that were not damaged by Sandy also showed a price penalty by $8 \%$ in the year 2017 due to increased risk perceptions of the natural disaster [36]. From the study on hurricanes Irene (2011) and Sandy (2012), Botzen, et al. [40] indicated that past experiences with flooding, rather than the flood probability, have a large influence on flood risk perceptions.

Relatively few studies were developed identifying the economic effects associated with on-site adaptation measures. Fell and Kousky [41] found that levee-protected commercial properties sell for approximately $8 \%$ more than similar properties in 100-year floodplains without such protection. Jin, Hoagland, Au and Qiu [8] indicated that single-family homes located behind a seawall within 160 feet of waterbodies have a $10 \%$ price appreciation due to anticipated risk reduction against inundation.

Quantitative studies of valuing green infrastructure and private adaptive measures on housing prices are mostly limited. Watson, et al. [42] roughly suggested that wetlands reduce flood damage by 54-78\%. Green, et al. [43] argued that green infrastructure supports enhancing insurance value by reducing vulnerability and the costs of hard infrastructural adaptation to climate change. Natural green infrastructure can be more cost-effective than engineering approaches from a long-term perspective, since they generally have self-maintaining capacities and can host other ecosystem services [44,45]. In terms of private adaptive measures, McKenzie and Levendis [46] found that elevation has a positive relationship with sales prices, particularly in low-lying areas, and this elevation premium is pronounced after a high-powered storm. Fortifying building structures by implementing stricter building codes and reinforcing homes against major hurricanes yields a price premium [47].

Although coastal communities can reduce their risk exposure by investment in buildings and infrastructural resilience, it would be difficult to achieve long-term adaptive effects to climate change only with these approaches. Since limited budgets and resources prioritize certain climate adaptation projects in certain areas, poorer communities may be further marginalized by the risk exposure [48]. Thus, "addressing the social structural causes of vulnerability is essential" by enhancing adaptive capacity, which is "often associated with access to technology, high education levels, economic equity, and strong institutions" [49]. To maximize climate adaptation efforts, then, cities and local governments would need to include both the infrastructural adaptation and the adaptive capacity. 


\section{Data}

This study investigates the impacts of climate adaptation measures using single-family housing transaction data in MDC and NYC from July 1, 2009 to May 31, 2018. The study combines four large datasets from MDC, NYC, the Federal Emergency Management Agency (FEMA), and the National Oceanic and Atmospheric Administration (NOAA); datasets include property transaction data, neighborhood and amenity characteristics, and historical hurricane tracks and storm reports. Local market statistics such as unemployment rates, housing vacancy rates, and median household incomes are provided by the US Census Bureau.

\subsection{Housing}

The housing transaction data include typical structural information such as building square footage, lot size, building age, story, building occupancy status, and transaction prices with sales dates. Since the spatial coordination of each property is excluded in the NYC dataset, the addresses of each property were manually batch-geocoded with ArcGIS. Outliers (15,717 in MDC and 7541 in NYC) were excluded, such as homes with more than eight bedrooms, lot sizes greater than five acres, zero transaction price, and inflation adjusted price less than $\$ 60,000$ or more than $\$ 10$ million. Consequently, a total of 79,181 and 90,777 single-family housing units in MDC and NYC, respectively, are analyzed in this study. Of the dataset, approximately $24.6 \%$ in MCD and $16.5 \%$ in NYC were repeated sales.

To capture location-specific unobserved factors, the transaction data were clustered by 270 and 1186 census tracts in MDC and NYC, respectively. Housing sales prices were seasonal index-adjusted prices. The inflation is also adjusted to January 2018 prices using each region's monthly consumer price index for housing. The average adjusted sales prices were $\$ 459,000$ in MDC and $\$ 614,000$ in NYC. About $70 \%$ of all transactions were within price ranges between $\$ 150,000$ and $\$ 800,000$ in MDC, and between $\$ 300,000$ and $\$ 800,000$ in NYC. The average age of housing structures in NYC (around 74 years) is about 24 years older than that of MDC (around 50 years per structure). A typical lot size in MDC is three times larger than that of NYC, but the average number of stories in NYC is twice as high as MDC. Approximately $80 \%$ are owner-occupied properties for both regions. Only about 7\% (in $\mathrm{MDC}$ ) and $1 \%$ (in NYC) of homes are bay-view properties.

\subsection{Major Storms}

A total of four major storms directly influenced MDC, and three storms impacted NYC from July 2009 to May 2018 (Figure 1). Each hurricane, with a homogeneous direction from the ocean to land, was large enough to impact the entirety of each region. However, the local impacts and associated risks should be dependent upon hurricane characteristics. For example, it is plausible that a higher probability of flooding from a hurricane that contains higher rainfalls can be anticipated. However, it is not always the case due to interactions with other factors, such as rainfall durations with forward-moving speed and drainage conditions in an area, for example. Thus, in order to identify the effects of storm characteristics on housing prices more precisely, three types of the most common and economically measurable elements (i.e., wind, flood, and storm surge), which describe each individual hurricane in the National Hurricane Center's tropical cyclone reports, are used in these analyses. Human casualty and damage amount were excluded in this study, as the human casualty is economically unmeasurable, while the damage amount is too extensive because it is generally aggregated at the state and/or even national level. 


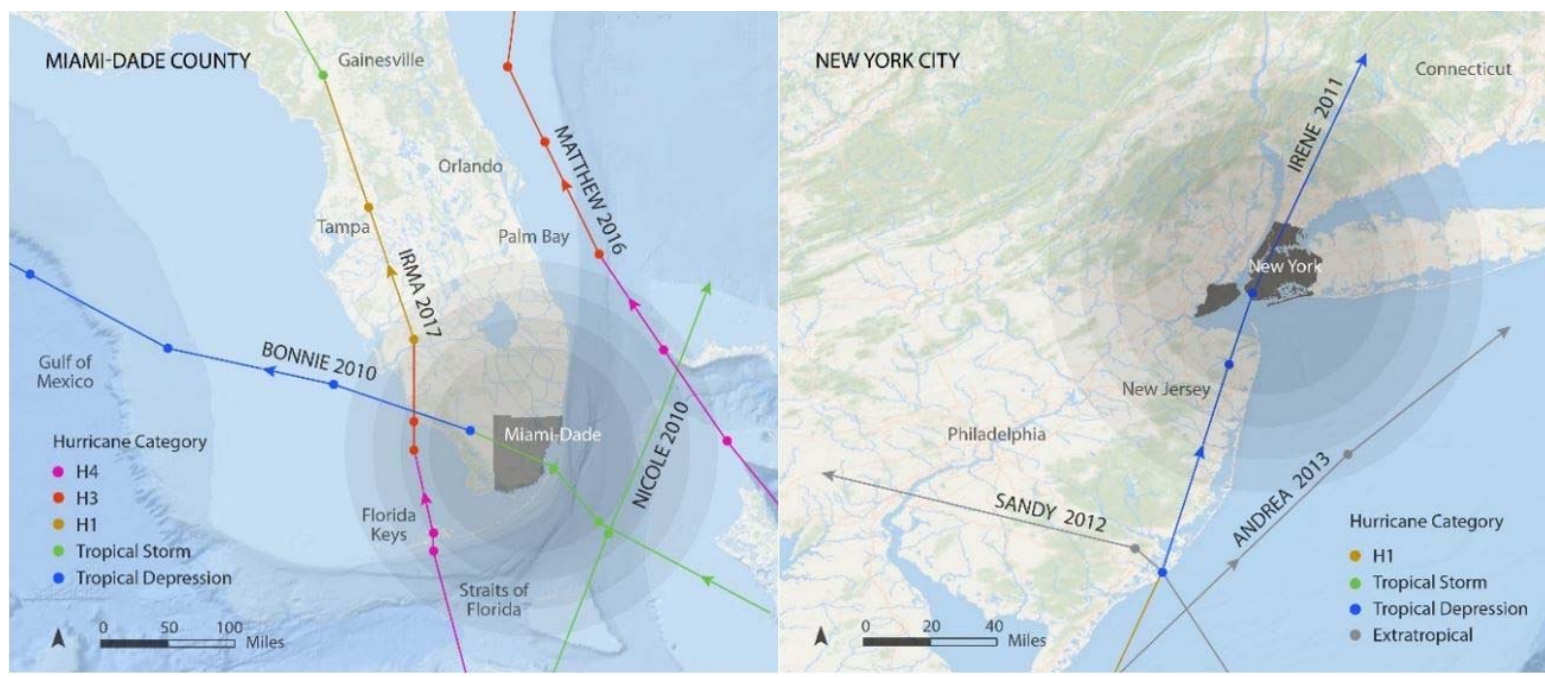

Figure 1. Site map with hurricane track between July 2009 and May 2018.

\subsection{Risk Perception Factors}

Since human cognitive processes largely influence the risk perception [50], I included the five factors (compression bias, anchoring effect, risk fadedness, miscalibration, and representativeness) to estimate risk perception relating to natural hazards in this study. These factors were reclassified from common intuitive biases which were identified in empirical risk perception studies [30,51-53].

Bogardus Jr, Holmboe and Jekel [53] classified four typical biases as compression bias (overestimating rare risks and underestimating common ones), availability heuristics (relying more on risk information that is more easily recalled), anchoring bias (the tendency to rely heavily on initial piece of information), and miscalibration (overconfidence about given facts). Rohrmann and Renn [52] additionally described the concepts of representativeness (the tendency to use heuristics to reach decisions efficiently) and cognitive dissonance (the propensity to seek consistency when new information is contrary to their beliefs) as a common intuitive bias of risk perception. Pryce, Chen and Galster [30] proposed the concept of myopia (discounting perceived risks from anticipated future disasters) and amnesia (forgetting past events over time) in their study analyzing the impact of floods on housing prices.

Compression bias refers to the human's propensity to exaggerate rare risks and underestimate recurring risks. In this case, a less frequent storm experience would have a greater impact on housing prices. In order to identify the compression bias for this study, I constructed storm frequency data from calculating the total number of storms that a homeowner experienced during the holding period. Anchoring bias can be measured by storm intensities that occupants experienced. Since the intensity of storms can be an "anchoring' factor in risk perceptions, I used the strongest hurricane category (which is based on wind speed) that a homeowner experienced during the holding period, regardless of the storm frequency [54]. Amnesia effect is renamed risk fadedness in this study because the perceived risk fades over time, rather than being completely erased at a certain point. This human bias suggests that risk perception would be much stronger immediately after a hurricane strikes, then gradually fading. To identify this risk fadedness effect, I created the elapsed periods between the previous storm strikes and home sales transaction dates for each property [55]. Insurance information represents miscalibration bias because homeowners can be overconfident about flood insurance and, thus, could also have an influence on the individual risk cognition. To measure this bias, I added a dummy variable that indicates flood insurance requirements for individual properties based on the flood insurance rate map (FIRM). Adaptation information can be another important factor in estimating the effects of representativeness bias. Similar to the precedent studies on whether risk information without actual damage can also impact housing prices [25], personal heuristics about adaptation projects can be a considerable factor. Therefore, expected project information without actual completion or rumors 
even before announcing an adaptation project can influence adjacent property values. To estimate the project information effect, I included another binary variable that identifies the sales transactions between the initial announcement and actual completion dates of the adaptation projects.

Meanwhile, availability bias and cognitive dissonance are not used in this study, because they are insignificant for this study due to the relatively short study period with small storm samples. Although myopia may impact on future home values with calculating probability [30], this bias is less related to natural hazard risks due to the uncertain nature of climate disasters.

\subsection{Climate Change Adaptation}

According to Miami-Dade County Emergency Management Office and New York Rising Community Reconstruction, a total of 305 (\$326 million) and 327 (\$1.62 billion) individual adaptation projects were implemented in each region during the study period (Figures 2 and 3). The individual project information includes project types and locations, initiation and completion dates, adaptation goals (i.e., which hazard to be addressed), construction stages, project costs, and detailed project descriptions. In order to analyze the effects of the implemented adaptation measures, I reclassify the individual projects into 10 categories (Figure 4).

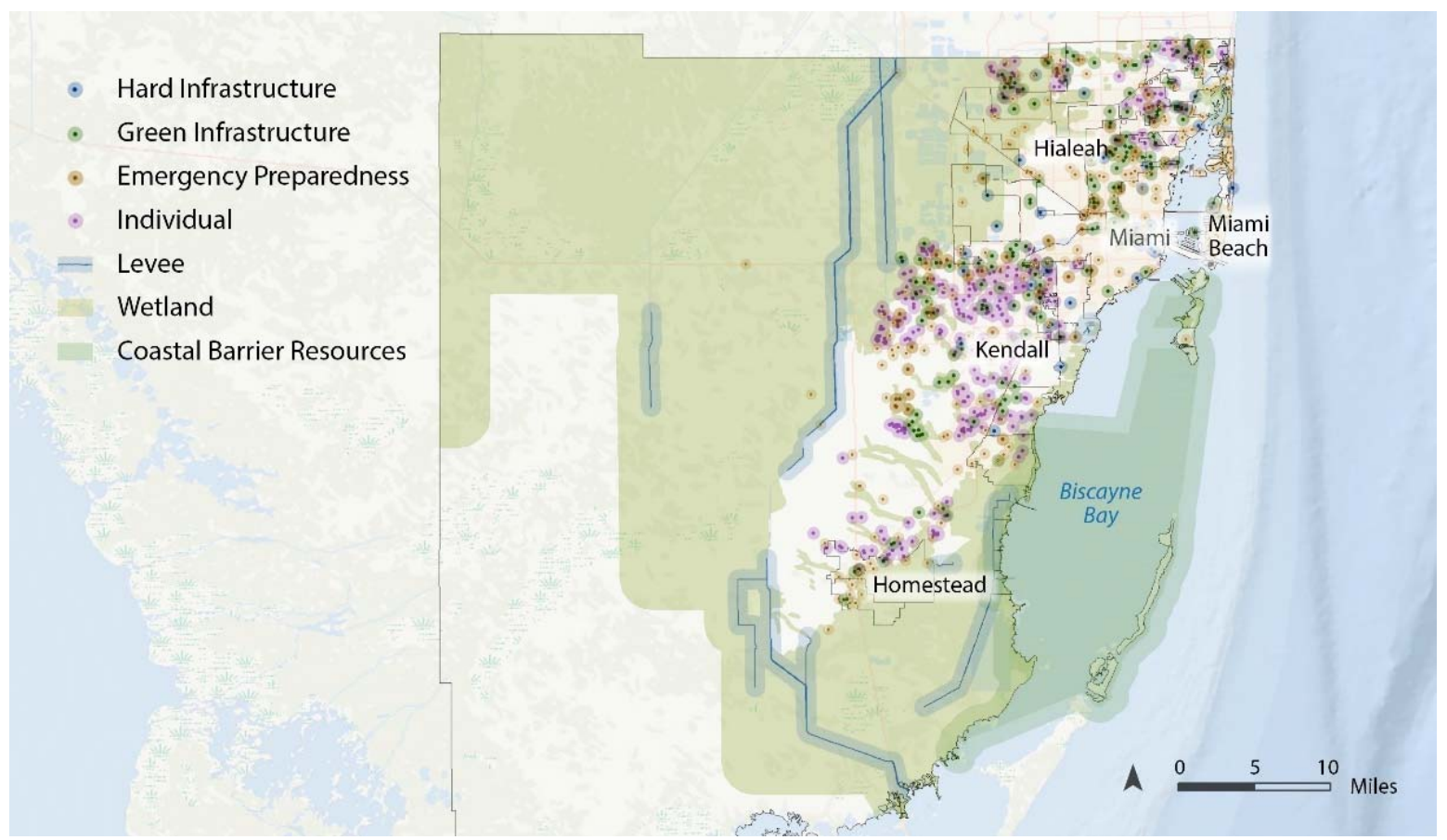

Figure 2. On-site adaptation measures in Miami-Dade County (MDC). Note: Each circle represents the ped-shed distance of a 400-m radius from hard and green infrastructure, emergency preparedness, and individual projects.

The first is "infrastructural adaptation." This project type includes hard infrastructure construction such as levees and storm barriers. Since the effects of existing infrastructure would already be reflected in housing prices, only newly added projects are considered in this subcategory. The second adaptation type is "public reinforcement" and includes all projects related to public service building (critical facilities) and infrastructural (e.g., elevating roadways) reinforcements. The third type is "drainage improvement." Erosion control and stormwater system improvement fall into this subcategory. The fourth type is "green infrastructure." Improvement of coastal barrier resource systems (CBRS), such as wetlands, lagoons, and salt marshes, as well as green space restoration and beach nourishment, is included in this subcategory. The fifth type is "adaptation facility" and includes provision of new critical facilities to prepare future events. The sixth type is "equipment retrofitting" and includes 
on-site power generators and installation of pump stations. The seventh type is "hurricane shelter" and includes both existing and new hurricane ready shelters. The eighth and ninth types are based on floodplain revision, but the eight type is elevating housing structure while the ninth type is a modification of the base flood elevation (BFE) by land (based on FEMA's Letter of Map Revision). The last type is "private building reinforcement" such as installing hurricane shutters, storm panels, and individual property-specific drainage improvements, as well as elevating building foundation by their own expenses.

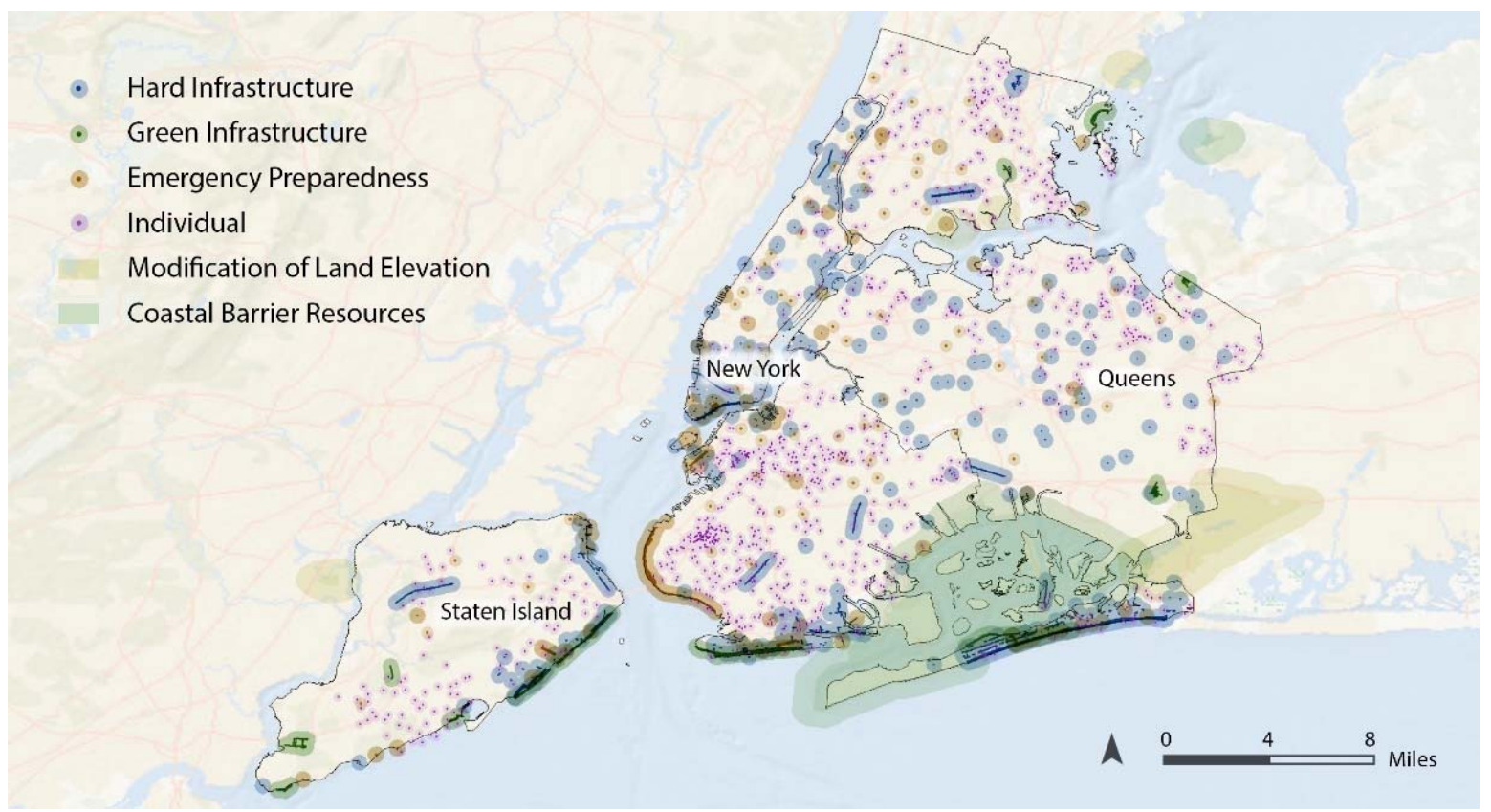

Figure 3. On-site adaptation measures in New York City (NYC). Note: Each circle represents the ped-shed distance of a 400-m radius from hard and green infrastructure, emergency preparedness, and individual projects.

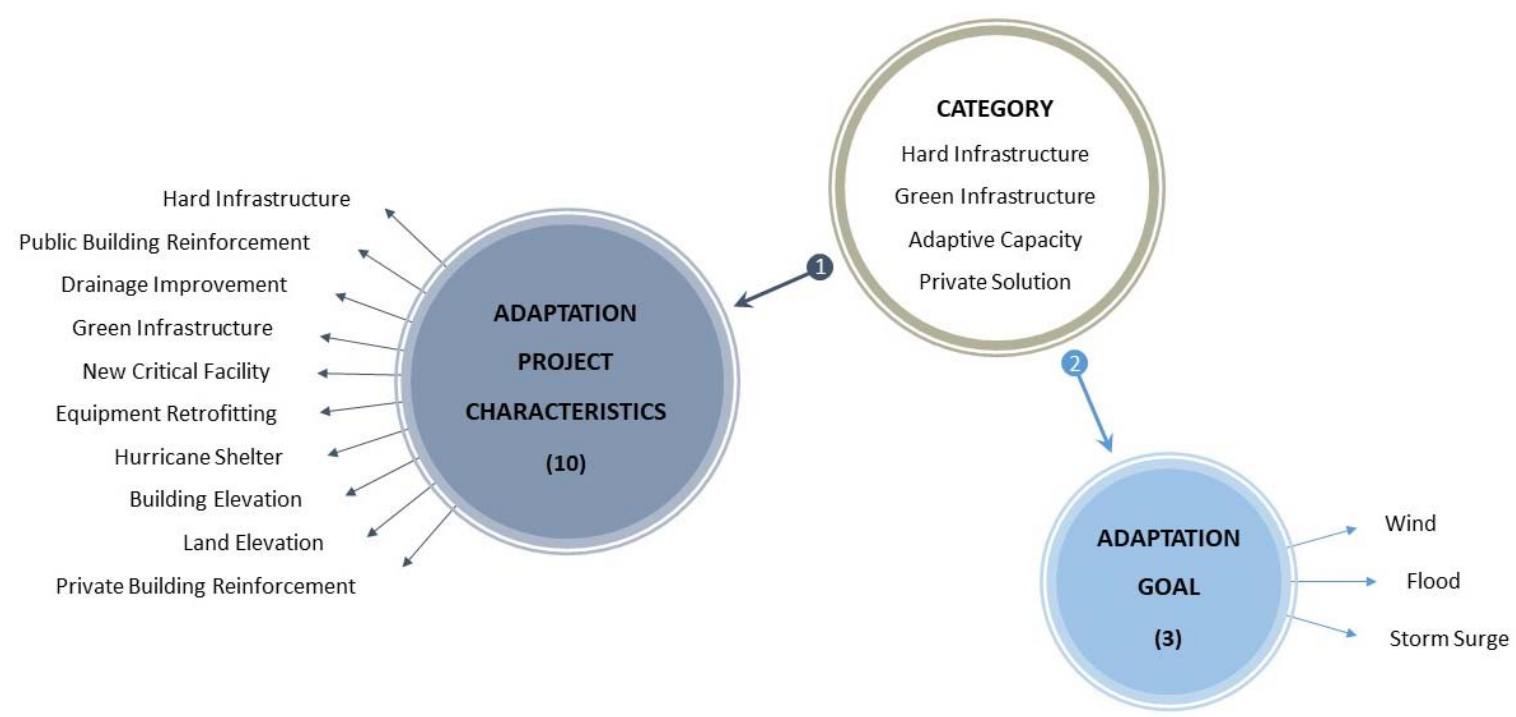

Figure 4. Analysis categories of adaptation measures.

\section{Method}

This study uses a panel data hedonic pricing model and the DID. Hedonic pricing is an economic technique that decomposes a property's sale price into a set of non-market characteristics, thereby 
quantifying the effects of the inherent attributes associated with the property on housing sales price. I applied this pricing model to estimate the impacts of climate change adaptation measures on single-family housing transaction prices in MDC and NYC over the last decade. Due to the foreseeable effects of risk dynamics, this study also includes risk perception factors and individual storm characteristics. A semi-log model is widely adopted in the hedonic literature [56]. In addition, due to expected nonlinear effects and the overall site characteristics in this analysis, the multiple semi-log regression model is most suitable for examining the effects of climate change adaptation measures on property values. However, the coefficients in the hedonic pricing model could be biased due to omitted variables and misspecification [57]. To adequately support the empirical criteria, I additionally use the DID specification with detailed adaptation project data to identify the treatment and control groups.

From the adaptation policies based on storm characteristics, it would be interesting to identify the adaptation effects on housing prices by project goals (e.g., what hazard to be addressed). I included additional adaptation classification by recalibrating the adaptation projects based on hazard types to be addressed (Figure 4). The rest of this section is organized as follows: Section 4.1 illustrates how the storm impacts on housing markets are estimated by the hedonic pricing method. Sections 4.2 and 4.3 describe different methods (hedonic pricing model vs. DID framework) for ensuring robustness to measure the effects of adaptation measures on housing prices.

\subsection{Storm Impacts on Housing Markets}

The first model is to examine whether storms impact housing prices or not. Regardless of storm impacts on housing prices, risk perception factors may still influence the impacts of adaptation policies on housing prices. However, the pricing effects of storms may influence risk perceptions that are reflected in people's economic decisions. Thus, the common trend assumption of storm impacts on housing prices should be tested first. To estimate this pricing trend, I constructed specific sales time windows after each storm. As a rule of thumb, damage recovery generally takes about five months in the study areas, and the housing market remains relatively slow-moving [58,59]. I set the market impact intervals for every 150 days. For example, the first sales window includes all transactions between 30 and 150 days after each storm. The second window includes the transactions occurring between 150 and 300 days after an event. Since a given housing sales transaction typically takes around one month on average, the transaction decisions immediately after storm strikes would not be related to the storm experiences. Thus, the transactions within 30 days after storms were excluded from the first sales window. The equation of the first model for estimating storm effects in different sales windows is specified as follows:

$$
\ln P_{i c t}=\alpha_{0}+\alpha_{1} X_{i}+\alpha_{2} N_{i}+\alpha_{3} M_{i z y}+\alpha_{4} S_{t o r m}+w_{c}+c_{y}+\varepsilon_{i c t}
$$

where $\ln P_{i c t}$ is the natural $\log$ of the sales price (inflation and seasonality adjusted) of single-family property $i$ in census tract $c$ in day $t, X_{i}$ and $N_{i}$ are vectors of house and location characteristics, respectively (Table 1), $M_{i c y}$ is a vector of market factors to property $i$ in zip code $z$ in year $y$, Storm $t$ represents housing transaction dummies representing the sales windows post hurricanes with 150-day intervals (e.g., 30-150 days, 150-300 days, and 300-450 days), $w_{c}$ represents the census tract fixed effects, $c_{y}$ includes year fixed effects, and $\varepsilon_{i c t}$ is the error term. In all models, the standard errors are clustered at the census tract level. 
Table 1. Definition and summary statistics of key variables.

\begin{tabular}{|c|c|c|c|c|c|}
\hline \multirow[t]{2}{*}{ Variables } & & \multicolumn{2}{|c|}{$\begin{array}{c}\text { MDC } \\
(n=79,181)\end{array}$} & \multicolumn{2}{|c|}{$\begin{array}{c}\text { NYC } \\
(n=90,777)\end{array}$} \\
\hline & & Mean & SD & Mean & SD \\
\hline \multirow[t]{2}{*}{ Price } & Sales price of single-family home $(\$ 100,000)$ & 4.10 & 5.45 & 6.03 & 5.22 \\
\hline & Storm impact periods & & & & \\
\hline H30-150 & 1 if a home sold between 30 and 150 days post-hurricanes & 0.127 & 0.332 & 0.099 & 0.299 \\
\hline H150-300 & 1 if a home sold between 150 and 300 days post-hurricanes & 0.145 & 0.352 & 0.124 & 0.330 \\
\hline Н300-450 & 1 if a home sold between 300 and 450 days post-hurricanes & 0.110 & 0.313 & 0.133 & 0.340 \\
\hline H450-600 & 1 if a home sold between 450 and 600 days post-hurricanes & 0.101 & 0.301 & 0.128 & 0.334 \\
\hline \multirow[t]{2}{*}{ H600-750 } & 1 if a home sold between 600 and 750 days post-hurricanes & 0.072 & 0.259 & 0.143 & 0.350 \\
\hline & Storm characteristics & & & & \\
\hline Wind & Sustained wind speed (knots) & 12.3 & 30.1 & 12.4 & 23.4 \\
\hline Rainfall & Total amount of rainfall (inch) & 1.10 & 2.36 & 1.00 & 2.10 \\
\hline \multirow[t]{2}{*}{ Surge } & Storm surge heights of affected homes (feet) & 0.079 & 0.463 & 0.217 & 0.467 \\
\hline & Risk-perception factors & & & & \\
\hline Frequency & Number of hurricanes between buying and selling home & 0.515 & 1.17 & 0.758 & 1.17 \\
\hline Intensity & Strongest hurricane category that homeowners experienced & 0.647 & 1.59 & 0.318 & 0.613 \\
\hline Fadedness & Elapsed period of time from hurricane to housing transactions & 37.1 & 89.0 & 29.7 & 83.1 \\
\hline Insurance & 1 if an insurance purchase is required $*$ & 0.364 & 0.481 & 0.040 & 0.197 \\
\hline \multirow[t]{2}{*}{ Information } & 1 if a home sold between project announcement and completion dates * & 0.011 & 0.106 & 0.012 & 0.107 \\
\hline & & & & & \\
\hline Infrastructure & 1 if a home is located within ped-shed ${ }^{* *}$ of new infrastructures* & 0.005 & 0.067 & 0.021 & 0.143 \\
\hline Pub_Reinforce & $\begin{array}{l}1 \text { if a home is located within ped-shed }{ }^{* *} \text { of public building } \\
\text { reinforcement projects* }\end{array}$ & 0.001 & 0.032 & 0.013 & 0.113 \\
\hline \multirow{3}{*}{$\begin{array}{l}\text { Drainage } \\
\text { Green } \\
\text { Facility }\end{array}$} & 1 if a home is located within ped-shed ${ }^{* *}$ of drainage projects* & 0.027 & 0.162 & 0.010 & 0.097 \\
\hline & 1 if a home is located within ped-shed ${ }^{* *}$ of green infrastructures* & 0.166 & 0.372 & 0.007 & 0.081 \\
\hline & 1 if a home is located within ped-shed ${ }^{* *}$ of new public facilities* & 0.001 & 0.023 & 0.001 & 0.024 \\
\hline Equipment & $\begin{array}{l}1 \text { if a home is located within ped-shed }{ }^{* *} \text { of equipment } \\
\text { retrofitting/installation projects* }\end{array}$ & 0.001 & 0.037 & 0.001 & 0.035 \\
\hline \multirow{3}{*}{$\begin{array}{l}\text { Shelter } \\
\text { Bldg_Elev } \\
\text { Land_Elev }\end{array}$} & 1 if a home is located within ped-shed ${ }^{* *}$ of hurricane shelters* & 0.025 & 0.158 & 0.004 & 0.199 \\
\hline & 1 if structure of home is elevated * & 0.001 & 0.094 & 0.001 & 0.094 \\
\hline & 1 if land of home is elevated * & 0.005 & 0.069 & 0.003 & 0.166 \\
\hline \multirow[t]{2}{*}{ Pri_Reinforce } & 1 if a home is reinforced by individual homeowners * & 0.008 & 0.091 & 0.010 & 0.099 \\
\hline & Adaptation goals & & & & \\
\hline Adp_Wind & 1 if a home is located within ped-shed ${ }^{* *}$ of wind adaptation * & 0.002 & 0.045 & 0.015 & 0.122 \\
\hline Adp_Flood & 1 if a home is located within ped-shed ${ }^{* *}$ of flood prevention $*$ & 0.182 & 0.386 & 0.002 & 0.039 \\
\hline Adp_Surge & 1 if a home is located within ped-shed ${ }^{* *}$ of storm surge projects * & 0.020 & 0.139 & 0.007 & 0.081 \\
\hline
\end{tabular}

${ }^{*}$ The variable is rated zero if the description is not met. ${ }^{* *}$ Ped-shed, the pedestrian shed, defined as the area covered

by a five-minute walk, or 400-m radius [60].

\subsection{Valuing Climate Change Adaptation Measures}

The second and third models are to identify the risk perception and adaptation effects on housing prices. The second model specification includes storm characteristics, the five risk-perception factors, and the 10 adaptation project characteristics. The third specification uses the adaptation variables reclassified by adaptation goals, instead of the adaptation variables used in the second model. The basic equation of the second and third models for estimating adaptation measures along with storm characteristics and risk-perception factors is as follows:

$$
\ln P_{i c t}=\alpha_{0}+\alpha_{1} X_{i}+\alpha_{2} N_{i}+\alpha_{3} M_{i z y}+\alpha_{4} H_{t}+\alpha_{5} R_{i}+\alpha_{6} \text { Adaptation }_{i c t}+w_{c}+c_{y}+\varepsilon_{i c t},
$$

where $H_{t}$ is a vector of hurricane characteristics on day $t$ and includes three major characteristics (wind speed, rainfall amount, and height of storm surge), while $R_{i}$ is a vector of the risk-perception factors to property $i$. This attribute group includes storm frequencies to test compression bias, storm intensities to estimate the anchoring effect, the elapsed date counts between previous storm strikes and home sales for the effects of risk fadedness, a dummy variable for flood insurance requirement to measure the miscalibration bias, and another dummy variable to distinguish homes sold between adaptation 
project announcement and project completion dates to estimate representativeness bias. Adaptation ${ }_{i c t}$ represents the 10 variables of the adaptation project characteristics and the three variables of the adaptation goals (Table 1). To distinguish the effects of adaptation projects that were already completed from the projects under construction at the point of sales transaction, I only include completed adaptation projects prior to a housing sale. All other variables are the same as in the Equation (1).

\subsection{Robustness Check: DID Estimation}

To examine the evidence for the robustness of the hedonic regression results, I adopt the DID approach. I construct the treatment and control groups by dividing housing samples based on the spatial distance to the nearest adaptation project of each of the 10 adaptation project characteristics and three adaptation goals. I choose the sample period to be all observations within a two-year window around the completion date of adaptation projects, one year before and after. The model is set as follows:

$$
\ln P_{\text {ict }}=\gamma_{0}+\gamma_{1} \text { Adaptation }_{i} \times \text { Open }_{t}+\gamma_{2} K_{i}+w_{c}+c_{m}+\varepsilon_{i c t},
$$

where Adaptation $_{i}$ is a dummy variable equal to one if a property $i$ is near to the adaptation measures and equal to zero otherwise, $\mathrm{Open}_{t}$ is an indicator variable that takes a value of one for all sales transactions after completion of adaptation projects and a value of zero before the adaptation projects, the vector of covariates $K_{i}$ refers to all other variables including structural variables, locational and market variables, storm characteristics, and risk-perception factors, $w_{\mathcal{c}}$ represents census tract fixed effects, $c_{m}$ includes month fixed effects, and $\varepsilon_{i c t}$ is the error term.

\section{Results and Discussion}

The regression results indicate that the relationship between the dependent variable and the independent variables is strong (adjusted $R^{2}=0.79$ for MDC and 0.57 for NYC). The majority of the variables' $p$-values are smaller than 0.05 , and the joint hypothesis f-statistics on each attribute group rejects the null hypothesis at the $1 \%$ level. Therefore, the panel data hedonic regressions are statistically significant.

\subsection{Structural and Locational Variables (Appendices A and B)}

As anticipated, all of the housing structural variables have a positive relationship with transaction prices. Larger building size and lot square footage, more stories, and recently built homes are associated with a housing sales price increase. Proximity to subway stations, bus stops, and schools has a negative relation to housing prices in MDC, but it is positively associated with home value increases in NYC. Although the majority of empirical findings indicated that public transportation proximity is positively associated with property value increases [61-63], the "net nuisance" effect can be caused by public transportation, and school proximity penalty, such as traffic congestion and noise, could overshadow the proximity benefits.

As expected, five-minute walkability to major commercial facilities, such as a major mall or shopping center, in both regions, and green space view and bay-view variables in NYC have a positive relation to home values. Brownfields are negatively associated with housing prices at $5 \%$ and $1 \%$ significance levels in MDC and NYC, respectively. Higher unemployment and housing vacancy rates are associated with housing price decreases in NYC, but they are statistically insignificant in MDC. I surmise that more land availability in MDC (population density in MDC is 20 times lower than in NYC) could influence the market variables.

\subsection{Storm Impact on Housing Market (Table 2, Model 1)}

The regression results show that hurricanes are strongly associated with housing price decreases. The non-linear trends on storm impact periods in model 1 (Table 2) suggest that other external factors 
(such as market factors, risk perceptions, and efficacy of adaptation measures) may also affect the housing markets.

The coefficient of H30-150 variable implies that single-family properties sold between 30 and 150 days after a storm strike sell at a $2.2 \%$ and $1.5 \%$ discount on average compared with homes sold in the other period in MDC and NYC, respectively. The negative impact of the storm becomes positive after five months following storm occurrences in MDC, while the adverse effects persist much longer in NYC, lasting around one year and a half. This contradictory impact over time signifies that risk perception and job market factors may be stronger than the power of housing market dynamics. If hurricanes affect the local housing supply and demand, the coefficient of H30-150 should be positive, due to the supply decrease caused by storm-induced property damages, but a negative result was observed in this study. This result indicates that either the majority of hurricane-damaged properties are still available in the market, or the local housing market dynamics are not much influenced by hurricanes. However, two plausible factors (job market and risk perception) may explain that there are negative impacts on housing prices during the first five months, followed by positive turns. Since hurricanes cause demand shocks in the job markets [64], these unemployment shocks can trigger increases in mortgage delinquency and foreclosure rates, resulting in housing vacancy escalation. The economic decline caused by hurricanes deters the inflow of job seekers, and subsequently higher unemployment rates can negatively impact the housing transaction prices. Another reason would be that a stronger risk awareness makes people hesitate to buy in. Consequently, housing demand decreases and, thus, housing prices drop for a few months.

Table 2. Summary results of hedonic regression (dependent variable: logged home value).

\begin{tabular}{|c|c|c|c|c|c|c|}
\hline \multirow{2}{*}{ Independent Variables } & \multicolumn{2}{|l|}{ Model 1} & \multicolumn{2}{|l|}{ Model 2} & \multicolumn{2}{|l|}{ Model 3} \\
\hline & MDC & NYC & MDC & NYC & MDC & NYC \\
\hline \multicolumn{7}{|l|}{ Storm impact periods } \\
\hline H $30-150$ & $-0.022^{* * *}$ & $-0.015^{* *}$ & & & & \\
\hline H150-300 & $0.022^{* *}$ & $-0.036^{* * *}$ & & & & \\
\hline H300-450 & 0.014 & $-0.017^{* *}$ & & & & \\
\hline H450-600 & -0.026 & $-0.034^{* * *}$ & & & & \\
\hline H600-750 & $0.027^{* *}$ & -0.008 & & & & \\
\hline \multicolumn{7}{|l|}{ Storm characteristics } \\
\hline Wind & & & 0.010 & $0.008^{* * *}$ & 0.010 & $0.008^{* *}$ \\
\hline Rainfall & & & $-0.036^{* * *}$ & $-0.048^{* *}$ & $-0.036^{* * *}$ & $-0.048^{* *}$ \\
\hline Surge & & & $-0.015^{* *}$ & $-0.032^{* *}$ & $-0.015^{* *}$ & $-0.031^{* *}$ \\
\hline \multicolumn{7}{|l|}{ Risk-perception factors } \\
\hline (Log)Frequency & & & $0.057^{* *}$ & 0.002 & $0.057^{* *}$ & 0.001 \\
\hline Intensity & & & $-0.017^{* * *}$ & $-0.012^{* * *}$ & $-0.017^{* * *}$ & $-0.012^{* * *}$ \\
\hline (Log)Fadedness & & & $0.003^{*}$ & $0.005^{*}$ & $0.003^{*}$ & $0.005^{*}$ \\
\hline Insurance & & & $0.030^{* * *}$ & $-0.086^{* * *}$ & $0.033^{* * *}$ & $-0.083^{* * *}$ \\
\hline Information & & & 0.019 & 0.014 & 0.020 & 0.018 \\
\hline \multicolumn{7}{|l|}{ Adaptation projects } \\
\hline Infrastructure & & & $0.111^{* * *}$ & $0.039^{*}$ & & \\
\hline Pub_Reinforce & & & -0.059 & 0.006 & & \\
\hline Drainage & & & 0.017 & $-0.011^{* * *}$ & & \\
\hline Green & & & $0.077^{* *}$ & $0.020^{* * *}$ & & \\
\hline Facility & & & -0.091 & 0.007 & & \\
\hline Equipment & & & 0.064 & $0.042^{* *}$ & & \\
\hline Shelter & & & -0.002 & 0.019 & & \\
\hline Bldg_Elev & & & $0.141^{* * *}$ & $0.117^{* * *}$ & & \\
\hline Land_Elev & & & -0.077 & $-0.136^{* *}$ & & \\
\hline Pri_Reinforce & & & 0.017 & $0.172^{* * *}$ & & \\
\hline
\end{tabular}


Table 2. Cont.

\begin{tabular}{|c|c|c|c|c|c|c|}
\hline \multirow{2}{*}{ Independent Variables } & \multicolumn{2}{|l|}{ Model 1} & \multicolumn{2}{|l|}{ Model 2} & \multicolumn{2}{|l|}{ Model 3} \\
\hline & MDC & NYC & MDC & NYC & MDC & NYC \\
\hline \multicolumn{7}{|l|}{ Adaptation goals } \\
\hline Adp_Wind & & & & & -0.033 & 0.014 \\
\hline Adp_Flood & & & & & $0.040 *$ & $0.017^{* * *}$ \\
\hline Adp_Surge & & & & & $0.062^{*}$ & $0.021^{* * *}$ \\
\hline Other variables & Yes & Yes & Yes & Yes & Yes & Yes \\
\hline Year dummies & Yes & Yes & Yes & Yes & Yes & Yes \\
\hline Census tract fixed effects & Yes & Yes & Yes & Yes & Yes & Yes \\
\hline Constant & $6.811^{* * *}$ & $9.905^{* * *}$ & $6.639^{* * *}$ & $9.885^{* * *}$ & $6.716^{* * *}$ & $9.897^{* * *}$ \\
\hline$N$ & 79,181 & 90,777 & 79,181 & 90,777 & 79,181 & 90,777 \\
\hline Adjusted $R^{2}$ & 0.793 & 0.569 & 0.793 & 0.572 & 0.793 & 0.571 \\
\hline
\end{tabular}

Notes: ${ }^{*} p<0.10,{ }^{* *} p<0.05,{ }^{* * *} p<0.01$. Each column reports the result from one regression with controls for space and time fixed effects by census tract and year dummies. Other variables include structural and locational variables. Standard errors are clustered at the census tract level. See Appendix for full regression results.

\subsection{Storm Characteristics and Risk Perception Factors (Table 2, Model 2)}

The majority of the storm characteristics and risk factors impact housing transaction prices. A stronger storm surge and more rainfall are associated with housing sales price depreciation in the two regions. Surprisingly, the results indicate that storms accompanying a higher wind speed have a positive influence on housing prices in both regions, although it is statistically insignificant in MDC. A plausible explanation is that the wind factor often influences a storm's movement speed. It is not always the case, but the forwarding wind speed is generally one of the factors determining the movement speed. If the movement speed is slow, greater flood damage would be anticipated due to increased rainfall on already fully saturated soils. Another possible reason supporting the result could include overestimation of the wind factor in the hurricane information. Current hurricane intensity (i.e., the Saffir-Simpson Scale) is largely based on sustained wind speeds, excluding other significant factors. However, there is much historical evidence to show that other storm characteristics should also be considered as well. For example, most of the damages in NYC from Super Storm Sandy in 2012 were caused by the extreme storm tide. In Puerto Rico, the major casualties from Hurricane Maria in 2017 were caused by rainfall-induced massive landslides.

Among the risk perception variables, the frequency variable has a positive effect on housing prices in MDC and has a positive sign in NYC. The storm frequency is calculated by counting the number of storm experiences that a homeowner has before the home transaction to a new homebuyer, and the homeowner's risk perception to the storms is affected by the frequency because the compression bias is applied-more storm experiences would lead homeowners to underestimate the actual risks, while a rare storm experience exaggerates the home seller's risk cognition. Stronger intensity of hurricane has a negative effect on home values in the two regions. This result confirms that anchoring bias impacts housing prices by the hurricane, while intensity works as the anchoring factor in risk perception. Fadedness has a positive impact on housing prices in both regions. The result indicates that homeowners have tendencies to forget past events over time. Insurance is positively associated with home value increases in MDC. This result suggests that homeowner's risk cognition can be altered by overconfidence about flood insurance, thus confirming that miscalibration bias exists. By contrast, the insurance variable has a negative effect on home values in NYC. A possible reason would be that higher insurance premiums, due to higher risk exposure, yield a lower housing sales price. The project information variable has a positive sign but is not statistically significant at any conventional levels of statistical significance in MDC and NYC. Thus, no effect of representativeness bias on housing prices is observed. Although homeowners would have a positive expectation about future adaptive projects, the nuisance effects from the construction activities, including noise, dust, and traffic congestion, would offset the positive effects. 


\subsection{Effects of Adaptation Measures (Tables 2 and 3)}

The 10 variables of adaptation measures were examined by estimating each project characteristic of application. To generalize the adaptation impacts by their adaptation goal, three recategorized variables from the 10 original categories were estimated. In light of the Kuminoff, Parmeter and Pope [57] study, I used the DID models to avert the bias resulting from omitted variables in the hedonic approach. Table 2 contains three major findings. Firstly, hard infrastructural measures, green infrastructural projects, and structural elevation projects are associated with housing price increases in both regions. Secondly, a particularly strong impact was observed on private adaptation (Pri_Reinforce) in NYC. Thirdly, adaptation projects to address wind hazard do not have a direct impact on housing prices.

The results are robust to regressions using the DID specification. The results of the DID estimates shown in Table 3 suggest that properties experienced a premium $(2.9 \%$ in MDC and $2.4 \%$ in NYC at the $5 \%$ and $10 \%$ significance levels, respectively) in areas proximate to adaptation compared to remote areas in the first year after completion of hard infrastructural adaptation projects. The coefficient of Infrastructure in NYC is relatively small (Table 2) and statistically significant at the $10 \%$ significance level (Tables 2 and 3). A plausible reason would be that the majority of NYC's hard infrastructural projects were relatively small and passive infrastructural projects, such as roadway elevation, pavement resurfacing, and breakwater installation for erosion controls, while MDC invested in active infrastructural projects including construction of levees and flood protection berms. These passive infrastructural projects would not have an influence as strong as the impact of active infrastructural projects on an individual homeowner's risk cognition.

Similarly, strong positive pricing effects of green infrastructure $11.8 \%$ in MDC and $4.6 \%$ in NYC at the $1 \%$ significance level) and building structural elevation (15\% in MDC and $16.7 \%$ in NYC at the $1 \%$ and $10 \%$ significance levels, respectively) were observed (Table 3 ). The green infrastructural projects in MDC are characterized by enhancing its functionality through expanding and retrofitting the existing features, while NYC projects focused more on restoring natural elements such as green spaces and sand dunes. Regardless of this distinction, overall green infrastructural projects in both regions preserve accessibility to natural amenities and recreational opportunities, as well as provide a similar function of planned retreat strategy by creating room to mitigate adverse impacts of hurricanes. It was interesting to note that land elevation appears to have a statistically significant negative impact on housing prices in NYC. One reason for this could be that it is difficult to raise the ground sufficiently above the base flood elevation on land with existing buildings, resulting in a little decrease in the flood insurance rate [65]. This limit may appear more in a high-density context of NYC where the regrading is limited due to the smaller average lot size.

Private adaptation is associated with housing price increases by $3.5 \%$ at the $1 \%$ significance level, while the variable is statistically insignificant in MDC (Table 3, Model 2). Plausible reasons that private adaptation measures are strong in New York City could result from issues related to the uneven spatial distribution of adaptation measures [66,67], as well as gaps between the level and quality of public provision and the social desirability of such adaptations [68]. In order words, residents far from the coastline could have the same magnitude of risk that the coastal residents have because the intensity of hurricanes can be strong enough to impact the entire city. However, public adaptation projects were mainly focused on the coastline communities and, thus, the benefits of public infrastructure are not equally distributed. Even if the distribution issue of adaptation provisions is considered to be minor, public adaptation cannot satisfy everybody due to its cost-effectiveness characteristics. Therefore, greater gaps between the level of public provision and individual desirability of adaptation result in a greater anticipated effect of private adaptation (i.e., elevating or reinforcing their properties).

With respect to another set of reclassifications by adaptation projects for each of the three hazard types, the projects that address flood and storm surge are positively associated with housing prices in both regions. Particularly strong coefficient values were observed for the flood adaptation $(10.3 \%)$ and storm surge adaptation (18.1\%) projects in MDC (Table 3). A plausible reason that adaptation projects to address wind hazard are not statistically significant at all specifications would be because 
hurricane wind force is overestimated by the hurricane warning system (the Saffir-Simpson Scale), which is largely based on wind speed [29].

Table 3. Effects of adaptation projects: difference-in-differences (DID) estimates. SE—standard error.

\begin{tabular}{ccccc}
\hline \multirow{2}{*}{ Variables } & \multicolumn{2}{c}{ Model 1 } & \multicolumn{2}{c}{ Model 2 } \\
NYC & \multicolumn{2}{c}{ Coefficient } & SE \\
\cline { 2 - 5 } & Coefficient & SE & $0.024^{*}$ & 0.013 \\
\hline Infrastructure $\times$ Open & $0.029^{* *}$ & 0.090 & 0.002 & 0.008 \\
Pub_Reinforce $\times$ Open & -0.042 & 0.251 & $-0.058^{* * *}$ & 0.011 \\
Drainage $\times$ Open & $0.062^{* *}$ & 0.032 & $0.046^{* * *}$ & 0.013 \\
Green $\times$ Open & $0.118^{* * *}$ & 0.029 & 0.020 & 0.025 \\
Facility $\times$ Open & 0.216 & 0.295 & -0.011 & 0.021 \\
Equipment $\times$ Open & -0.025 & 0.110 & 0.006 & 0.030 \\
Shelter $\times$ Open & -0.059 & 0.078 & $0.167^{*}$ & 0.118 \\
Bldg_Elev $\times$ Open & $0.150^{* * *}$ & 0.018 & $-0.074^{* *}$ & 0.029 \\
Land_Elev $\times$ Open & $0.042^{*}$ & 0.024 & $0.035^{* * *}$ & 0.072 \\
Pri_Reinforce $\times$ Open & 0.028 & 0.056 & -0.003 & 0.008 \\
\hline Adp_Wind $\times$ Open & 0.233 & 0.167 & $024^{*}$ & 016 \\
Adp_Flood $\times$ Open & $0.103^{* * *}$ & 0.024 & $046^{* * *}$ & 013 \\
Adp_Surge $\times$ Open & $0.181^{* * *}$ & 0.042 & Yes & \\
\hline All other variables & Yes & & Yes & \\
Time dummies & Yes & & Yes & \\
Census tract fixed effects & Yes & & 32,618 & \\
$N$ & 40,571 & & 0.576 & \\
Adjusted $R^{2}$ & 0.780 & & & \\
\hline
\end{tabular}

Notes: ${ }^{*} p<0.10,{ }^{* *} p<0.05,{ }^{* * *} p<0.01$. Each row reports the result from one regression with controls for space and time fixed effects by census tract and month dummies. Heteroscedasticity-robust standard errors are given in the next column after estimated coefficients. Standard errors are clustered at the census tract level.

\subsection{Adaptation Efficacy and Market Trend (Figure 5)}

To identify the market effects of adaptation efficacy, I scaled home sales prices to the average transaction prices of the homes sold within the first sales window. The indexed values indicate that effective adaptation measures (homes affected by the adaptation measures that have a positive impact on housing prices in each site) generally appreciate sales prices faster within five months of hurricane occurrences in both regions. Similarly, when adaptation is malfunctioning (homes influenced by the adaptation measures that have no impact or negative values), a rapid depreciation is also observed in MDC within the same period.

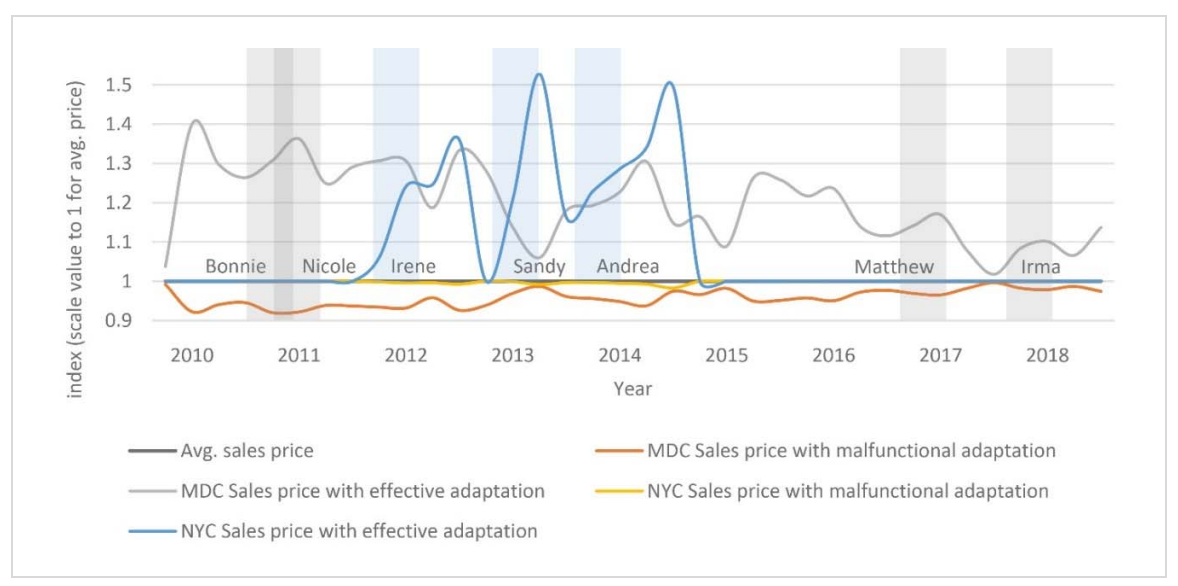

Figure 5. Home sales price changes based on the effectiveness of adaptation measures (scale value to one for average price). 


\section{Conclusions}

This study contributes to the literature on the effects of climate change adaptation measures on risk perception, as well as real estate market. Using single-family housing transactions, major storm data, and implemented adaptation measures over the last decade, I examined how the adaptation measures, risk-perception factors, and storm specific characteristics influence housing prices in these coastal communities. The results shed light on implemented climate adaptation effects on housing market dynamics. From the hedonic pricing model, I confirmed that the impacts of major storms on coastal housing prices are closely related to a temporary change in housing prices. With respect to the risk-perception factors, compression bias, anchoring bias, and risk fadedness consistently impact housing prices in both regions.

The study highlights that properties, in areas proximate to hard infrastructure, green infrastructure, and building structural elevation projects, experienced a housing price appreciation. Among these three, the pricing effects of green infrastructural adaptation projects $(11.8 \%)$ and structural elevation $(15 \%)$ were particularly strong in MDC at the $5 \%$ statistical significance level. The findings with the specific percentages of price premium contribute to existing green infrastructure literature, which mostly provides a quite rough price estimate [42,43].

Adapting for storm surges provided the largest positive impact on housing prices by $18.1 \%$ in MDC among the variables in the DID specifications. Unlike other large-scale development projects or urban infrastructure provisions, adaptation project information does not effectively influence reducing adverse storm risks due to "net negative nuisance" effects.

Since climate risk is unavoidable in coastal areas, an accurate understanding of the effects of adaptation measures on housing prices will greatly help those who engage in real estate investment and development in coastal areas. Furthermore, this study helps to provide a clearer understanding of how climate adaptation efforts, storm characteristics, and risk perception can also be directly or indirectly related to improving coastal community resiliency.

Funding: This research received no external funding.

Conflicts of Interest: The author declares no conflict of interest.

\section{Appendix A}

Table A1. Definition and Summary Statistics of Covariates.

\begin{tabular}{|c|c|c|c|c|c|}
\hline \multirow[t]{2}{*}{ Variables } & & \multicolumn{2}{|c|}{$\begin{array}{c}\text { MDC } \\
(n=79,181)\end{array}$} & \multicolumn{2}{|c|}{$\begin{array}{c}\text { NYC } \\
(n=90,777)\end{array}$} \\
\hline & & Mean & SD & Mean & SD \\
\hline \multicolumn{6}{|c|}{ Structural variables } \\
\hline Bldgsf & Building square footage (thousands) & 2.33 & 1.19 & 1.63 & 0.666 \\
\hline Area & Lot square footage (thousands) & 10.3 & 8.53 & 3.28 & 2.32 \\
\hline Story & Number of stories & 1.12 & 0.328 & 2.47 & 0.627 \\
\hline Age & Building age (year) & 50.2 & 20.6 & 74.3 & 27.0 \\
\hline Occupancy & 1 if a property is owner-occupied; 0 otherwise & 0.814 & 0.389 & 0.801 & 0.399 \\
\hline Elevation & Ground elevation above sea level (feet) & 8.17 & 2.46 & 57.5 & 46.4 \\
\hline \multicolumn{6}{|c|}{ Locational variables } \\
\hline Metro & 1 if a home is within $400 \mathrm{~m}$ of metro stations; 0 otherwise & 0.003 & 0.055 & 0.024 & 0.153 \\
\hline Bus & 1 if a home is within $400 \mathrm{~m}$ of bus stops; 0 otherwise & 0.662 & 0.473 & 0.230 & 0.421 \\
\hline Commercial & 1 if a home is within $400 \mathrm{~m}$ of major malls; 0 otherwise & 0.003 & 0.052 & 0.802 & 0.399 \\
\hline School & 1 if a home is within $400 \mathrm{~m}$ of schools; 0 otherwise & 0.388 & 0.487 & 0.295 & 0.456 \\
\hline Brownfield & 1 if a home is within brownfield sites; 0 otherwise & 0.099 & 0.299 & 0.012 & 0.108 \\
\hline Greenview & 1 if a home has a green space view; 0 otherwise & 0.051 & 0.220 & 0.014 & 0.116 \\
\hline Bayview & 1 if a home has a bay-view; 0 otherwise & 0.074 & 0.261 & 0.011 & 0.103 \\
\hline \multicolumn{6}{|l|}{ Market variables } \\
\hline Unemploy & Annual unemployment rates by zip code (\%) & 0.095 & 0.035 & 0.085 & 0.030 \\
\hline Vacancy & Annual vacancy rates by zip code $(\%)$ & 0.114 & 0.084 & 0.069 & 0.010 \\
\hline Income & Annual median household income (thousand dollar) by zip code & 51.6 & 19.3 & 65.1 & 15.5 \\
\hline
\end{tabular}




\section{Appendix B}

Table A2. Full Results of Hedonic Regression.

\begin{tabular}{|c|c|c|c|c|c|c|}
\hline \multirow{2}{*}{ Variables } & \multicolumn{2}{|l|}{ Model 1} & \multicolumn{2}{|l|}{ Model 2} & \multicolumn{2}{|l|}{ Model 3} \\
\hline & MDC & NYC & MDC & NYC & MDC & NYC \\
\hline$(\log )$ Bldgsf & $0.048^{* * *}$ & $0.044^{* * *}$ & $0.047^{* * *}$ & $0.044^{* * *}$ & $0.047^{* * *}$ & $0.044^{* * *}$ \\
\hline$(\log )$ Area & $0.026^{* * *}$ & $0.015^{* * *}$ & $0.026^{* * *}$ & $0.015^{* * *}$ & $0.026^{* * *}$ & $0.015^{* * *}$ \\
\hline (log)Story & $0.027^{* * *}$ & $0.006^{* * *}$ & $0.026^{* * *}$ & $0.006^{* * *}$ & $0.026^{* * *}$ & $0.006^{* * *}$ \\
\hline (log)Age & $-0.072^{* * *}$ & $-0.025^{* * *}$ & $-0.069^{* * *}$ & $-0.027^{* * *}$ & $-0.071^{* * *}$ & $-0.026^{* * *}$ \\
\hline Occupancy & $0.084^{* * *}$ & 0.006 & $0.084^{* * *}$ & 0.006 & $0.084^{* * *}$ & 0.006 \\
\hline (log)Elevation & 0.019 & -0.059 & $0.043^{* *}$ & -0.063 & $0.044^{* *}$ & -0.065 \\
\hline Metro & -0.046 & $0.017^{* * *}$ & -0.043 & $0.017^{* * *}$ & -0.047 & $0.017^{* * *}$ \\
\hline Bus & $-0.032^{* * *}$ & $0.016^{* *}$ & $-0.029^{* * *}$ & $0.015^{* *}$ & $-0.028^{* * *}$ & $0.015^{* *}$ \\
\hline Commercial & $0.081^{* *}$ & $0.039^{* * *}$ & $0.070^{* *}$ & $0.040^{* * *}$ & $0.071^{* *}$ & $0.039^{* * *}$ \\
\hline School & $-0.021^{* * *}$ & $0.032^{* * *}$ & $-0.020^{* * *}$ & $0.031^{* * *}$ & $-0.020^{* * *}$ & $0.032^{* * *}$ \\
\hline Brownfield & $-0.077^{* *}$ & $-0.069^{* * *}$ & $-0.078^{* *}$ & $-0.063^{* *}$ & $-0.077^{* *}$ & $-0.072^{* * *}$ \\
\hline Greenview & -0.010 & $0.047^{* *}$ & -0.009 & $0.047^{* *}$ & -0.010 & $0.046^{* *}$ \\
\hline Bayview & 0.006 & $0.042^{*}$ & 0.000 & $0.055^{* *}$ & 0.003 & $0.059^{* * *}$ \\
\hline (log)Unemploy & 0.060 & $-0.046^{* * *}$ & 0.052 & $-0.046^{* * *}$ & 0.054 & $-0.046^{* * *}$ \\
\hline (log)Vacancy & 0.033 & $-0.012^{* * *}$ & 0.028 & $-0.011^{* * *}$ & 0.031 & $-0.011^{* * *}$ \\
\hline (log)Income & -0.007 & 0.027 & 0.003 & 0.029 & -0.004 & 0.028 \\
\hline Н30-150 & $-0.022^{* * *}$ & $-0.015^{* *}$ & & & & \\
\hline H150-300 & $0.022^{* *}$ & $-0.036^{* * *}$ & & & & \\
\hline H300-450 & 0.014 & $-0.017^{* *}$ & & & & \\
\hline H450-600 & -0.026 & $-0.034^{* * *}$ & & & & \\
\hline H600-750 & $0.027^{* *}$ & -0.008 & & & & \\
\hline Wind & & & 0.010 & $0.008^{* * *}$ & 0.010 & $0.008^{* *}$ \\
\hline Rainfall & & & $-0.036^{* * *}$ & $-0.048^{* *}$ & $-0.036^{* * *}$ & $-0.048^{* *}$ \\
\hline Surge & & & $-0.015^{* *}$ & $-0.032^{* *}$ & $-0.015^{* *}$ & $-0.031^{* *}$ \\
\hline (log)Frequency & & & $0.057^{* *}$ & 0.002 & $0.057^{* *}$ & 0.001 \\
\hline Intensity & & & $-0.017^{* * *}$ & $-0.012^{* * *}$ & $-0.017^{* * *}$ & $-0.012^{* * *}$ \\
\hline (log)Fadedness & & & $0.003^{*}$ & $0.005^{*}$ & $0.003^{*}$ & $0.005^{*}$ \\
\hline Insurance & & & $0.030^{* * *}$ & $-0.086^{* * *}$ & $0.033^{* * *}$ & $-0.083^{* * *}$ \\
\hline Information & & & 0.019 & 0.014 & 0.020 & 0.018 \\
\hline Infrastructure & & & $0.111^{* * *}$ & $0.039^{*}$ & & \\
\hline Pub_Reinforce & & & -0.059 & 0.006 & & \\
\hline Drainage & & & 0.017 & $-0.011^{* * *}$ & & \\
\hline Green & & & $0.077^{* *}$ & $0.020^{* * *}$ & & \\
\hline Facility & & & -0.091 & 0.007 & & \\
\hline Equipment & & & 0.064 & $0.042^{* *}$ & & \\
\hline Shelter & & & -0.002 & 0.019 & & \\
\hline Bldg_Elev & & & $0.141^{* * *}$ & $0.117^{* * *}$ & & \\
\hline Land_Elev & & & -0.077 & $-0.136^{* *}$ & & \\
\hline Pri_Reinforce & & & 0.017 & $0.172^{* * *}$ & & \\
\hline Adp_Wind & & & & & -0.033 & 0.014 \\
\hline Adp_Flood & & & & & $0.040^{*}$ & $0.017^{* * *}$ \\
\hline Adp_Surge & & & & & $0.062^{*}$ & $0.021^{* * *}$ \\
\hline Constant & $6.811^{* * *}$ & $9.905^{* * *}$ & $6.639^{* * *}$ & $9.885^{* * *}$ & $6.716^{* * *}$ & $9.897^{* * *}$ \\
\hline Observations & 79,181 & 90,777 & 79,181 & 90,777 & 79,181 & 90,777 \\
\hline Adjusted $R^{2}$ & 0.793 & 0.569 & 0.793 & 0.572 & 0.793 & 0.571 \\
\hline
\end{tabular}

Notes: ${ }^{*} p<0.10,{ }^{* *} p<0.05,{ }^{* * *} p<0.01$. The main entries in each column report the coefficients are estimated from Equation (1) by panel data hedonic pricing model, with controls for space and time fixed effects by census tract and year dummies. Standard errors are clustered at census tract level. 


\section{References}

1. Rosenzweig, C.; Solecki, W.D.; Blake, R.; Bowman, M.; Faris, C.; Gornitz, V.; Horton, R.; Jacob, K.; LeBlanc, A.; Leichenko, R. Developing coastal adaptation to climate change in the New York City infrastructure-shed: Process, approach, tools, and strategies. Clim. Chang. 2011, 106, 93-127. [CrossRef]

2. Smith, A. 2017 U.S. Billion-Dollar Weather and Climate Disasters: A Historic Year in Context. National Oceanic and Atmospheric Administration. 2018. Available online: https://www.climate.gov/newsfeatures/blogs/beyond-data/2017-us-billion-dollar-weather-and-climate-disasters-historic-year (accessed on 26 October 2018).

3. Bin, O.; Crawford, T.W.; Kruse, J.B.; Landry, C.E. Viewscapes and flood hazard: Coastal housing market response to amenities and risk. Land Econ. 2008, 84, 434-448. [CrossRef]

4. Atreya, A.; Czajkowski, J. Is Flood Risk Universally Sufficient to Offset the Strong Desire to Live Near the Water; Risk Management and Decision Processes Center, The Wharton School of the University of Pennsylvania: Philadelphia, PA, USA, 2014.

5. Barbier, E.B. A global strategy for protecting vulnerable coastal populations. Science 2014, 345, $1250-1251$. [CrossRef] [PubMed]

6. Hino, M.; Field, C.B.; Mach, K.J. Managed retreat as a response to natural hazard risk. Nat. Clim. Chang. 2017, 7, 364. [CrossRef]

7. Bunten, D.; Kahn, M.E. Optimal real estate capital durability and localized climate change disaster risk. J. Hous. Econ. 2017, 36, 1-7. [CrossRef]

8. Jin, D.; Hoagland, P.; Au, D.K.; Qiu, J. Shoreline change, seawalls, and coastal property values. Ocean Coast. Manag. 2015, 114, 185-193. [CrossRef]

9. Mills-Knapp, S.; Bourdeau, E.; Falco, G.; Resler, C.; Tovar, H.; Zoegall, S. Climate Change Adaptation and Sustainable Design at the Port Authority of New York and New Jersey; Earth Institute, Columbia University: New York, NY, USA, 2011.

10. Fresque-Baxter, J.A.; Armitage, D. Place identity and climate change adaptation: A synthesis and framework for understanding. Wiley Interdiscip. Rev. Clim. Chang. 2012, 3, 251-266. [CrossRef]

11. Boulton, E. Climate change as a 'hyperobject': A critical review of Timothy Morton's reframing narrative. Wiley Interdiscip. Rev. Clim. Chang. 2016, 7, 772-785. [CrossRef]

12. Mendelsohn, R. Efficient adaptation to climate change. Clim. Chang. 2000, 45, 583-600. [CrossRef]

13. NOAA. U.S. Billion-Dollar Weather and Climate Disasters; National Centers for Environmental Information: Asheville, NC, USA, 2018.

14. NOAA. Historical Hurricane Tracks; National Oceanic and Atmospheric Administration: Silver Spring, MD, USA, 2018.

15. MDC. Local Mitigation Strategies (LMS) Project List; Miami-Dade County Open Data Hub: Miami-Dade County, FL, USA, 2017.

16. GOSR. New York Rising Community Reconstruction Program Project Map; New York State Government's Office of Storm Recovery (GOSR); New York Rising Community Reconstruction: Albany, NY, USA, 2019.

17. Conroy, S.J.; Milosch, J.L. An estimation of the coastal premium for residential housing prices in San Diego County. J. Real Estate Financ. Econ. 2011, 42, 211-228. [CrossRef]

18. Pompe, J.J. Establishing fees for beach protection: Paying for a public good. Coast. Manag. 1999, $27,57-67$. [CrossRef]

19. Benson, E.D.; Hansen, J.L.; Schwartz, A.L.; Smersh, G.T. Pricing residential amenities: The value of a view. J. Real Estate Financ. Econ. 1998, 16, 55-73. [CrossRef]

20. Landry, C.E.; Hindsley, P. Valuing beach quality with hedonic property models. Land Econ. 2011, 87, 92-108. [CrossRef]

21. Gopalakrishnan, S.; Smith, M.D.; Slott, J.M.; Murray, A.B. The value of disappearing beaches: A hedonic pricing model with endogenous beach width. J. Environ. Econ. Manag. 2011, 61, 297-310. [CrossRef]

22. Bin, O.; Polasky, S. Effects of flood hazards on property values: Evidence before and after Hurricane Floyd. Land Econ. 2004, 80, 490-500. [CrossRef]

23. Bin, O.; Kruse, J.B.; Landry, C.E. Flood hazards, insurance rates, and amenities: Evidence from the coastal housing market. J. Risk Insur. 2008, 75, 63-82. [CrossRef] 
24. Daniel, V.E.; Florax, R.J.; Rietveld, P. Flooding risk and housing values: An economic assessment of environmental hazard. Ecol. Econ. 2009, 69, 355-365. [CrossRef]

25. Hallstrom, D.G.; Smith, V.K. Market responses to hurricanes. J. Environ. Econ. Manag. 2005, 50, 541-561. [CrossRef]

26. Troy, A.; Romm, J. Assessing the price effects of flood hazard disclosure under the California natural hazard disclosure law (AB 1195). J. Environ. Plan. Manag. 2004, 47, 137-162. [CrossRef]

27. Kousky, C. Learning from extreme events: Risk perceptions after the flood. Land Econ. 2010, 86, $395-422$. [CrossRef]

28. Otto, P.; Mehta, A.; Liu, B. Mind the gap: Towards and beyond impact to enhance tropical cyclone risk communication. Trop. Cyclone Res. Rev. 2018, 7, 140-151.

29. Meyer, R.J.; Baker, J.; Broad, K.; Czajkowski, J.; Orlove, B. The dynamics of hurricane risk perception: Real-time evidence from the 2012 Atlantic hurricane season. Bull. Am. Meteorol. Soc. 2014, 95, 1389-1404. [CrossRef]

30. Pryce, G.; Chen, Y.; Galster, G. The impact of floods on house prices: An imperfect information approach with myopia and amnesia. Hous. Stud. 2011, 26, 259-279. [CrossRef]

31. Ewing, B.T.; Kruse, J.B.; Wang, Y. Local housing price index analysis in wind-disaster-prone areas. Nat. Hazards 2007, 40, 463-483. [CrossRef]

32. Murphy, A.; Strobl, E. The Impact of Hurricanes on Housing Prices: Evidence from US Coastal Cities; Federal Reserve Bank of Dallas: Dallas, TX, USA, 2010.

33. Beracha, E.; Prati, R.S. How major hurricanes impact housing prices and transaction volume. Real Estate Issues-Am. Soc. Real Estate Couns. 2008, 33, 45.

34. Below, S.; Beracha, E.; Skiba, H. The Impact of Hurricanes on the Selling Price of Coastal Residential Real Estate. J. Hous. Res. 2017, 26, 157-178.

35. Chivers, J.; Flores, N.E. Market failure in information: The national flood insurance program. Land Econ. 2002, 78, 515-521. [CrossRef]

36. Ortega, F.; Taspinar, S. Rising Sea Levels and Sinking Property Values: The Effects of Hurricane Sandy on New York's Housing Market. J. Urban Econ. 2018, 106, 81-100. [CrossRef]

37. Atreya, A.; Ferreira, S.; Kriesel, W. Forgetting the flood? An analysis of the flood risk discount over time. Land Econ. 2013, 89, 577-596. [CrossRef]

38. Bin, O.; Landry, C.E. Changes in implicit flood risk premiums: Empirical evidence from the housing market. J. Environ. Econ. Manag. 2013, 65, 361-376. [CrossRef]

39. Komarek, T.M.; Filer, L. Waiting after the storm: The effect of flooding on time on the housing market in coastal Virginia. Appl. Econ. Lett. 2019, 298-301. [CrossRef]

40. Botzen, W.; Kunreuther, H.; Michel-Kerjan, E. Divergence between individual perceptions and objective indicators of tail risks: Evidence from floodplain residents in new york city. Judgm. Decis. Mak. 2015, 10, 21.

41. Fell, H.; Kousky, C. The value of levee protection to commercial properties. Ecol. Econ. 2015, 119, 181-188. [CrossRef]

42. Watson, K.B.; Ricketts, T.; Galford, G.; Polasky, S.; O’Niel-Dunne, J. Quantifying flood mitigation services: The economic value of Otter Creek wetlands and floodplains to Middlebury, VT. Ecol. Econ. 2016, 130, $16-24$. [CrossRef]

43. Green, T.L.; Kronenberg, J.; Andersson, E.; Elmqvist, T.; Gomez-Baggethun, E. Insurance value of green infrastructure in and around cities. Ecosystems 2016, 19, 1051-1063. [CrossRef]

44. Bobbins, K.; Culwick, C. A Framework for a Green Infrastructure Planning Approach in the Gauteng City-Region; Gauteng City-Region Observatory: Johannesburg, South Africa, 2016.

45. Costanza, R.; Pérez-Maqueo, O.; Martinez, M.L.; Sutton, P.; Anderson, S.J.; Mulder, K. The value of coastal wetlands for hurricane protection. AMBIO J. Hum. Environ. 2008, 37, 241-248. [CrossRef]

46. McKenzie, R.; Levendis, J. Flood hazards and urban housing markets: The effects of Katrina on New Orleans. J. Real Estate Financ. Econ. 2010, 40, 62-76. [CrossRef]

47. Dumm, R.; Sirmans, G.S.; Smersh, G. Building code, wind contours, and house prices. J. Real Estate Res. 2012, 34, 73-98. 
48. De Coninck, H.; Revi, A.; Babiker, M.; Bertoldi, P.; Buckeridge, M.; Cartwright, A.; Dong, W.; Ford, J.; Fuss, S.; Hourcade, J. Strengthening and Implementing the Global Response; Intergovernmental Panel on Climate Change (IPCC): Geneva, Switzerland, 2018; pp. 313-443. Available online: https://www.ipcc.ch/sr15 (accessed on 12 November 2018).

49. O'Brien, K.; Selboe, E. The Adaptive Challenge of Climate Change; Cambridge University Press: Cambridge, UK, 2015.

50. Lavell, A.; Oppenheimer, M.; Diop, C.; Hess, J.; Lempert, R.; Li, J.; Muir-Wood, R.; Myeong, S. Climate change: New dimensions in disaster risk, exposure, vulnerability, and resilience. In Managing the Risks of Extreme Events and Disasters to Advance Climate Change Adaptation: Special Report of the Intergovernmental Panel on Climate Change; Cambridge University Press: Cambridge, UK, 2012.

51. Adams, A.; Smith, A. Risk perception and communication: Recent developments and implications for anaesthesia. Anaesthesia 2001, 56, 745-755. [CrossRef]

52. Rohrmann, B.; Renn, O. Risk perception research. In Cross-Cultural Risk Perception; Springer: Boston, MA, USA, 2000; pp. 11-53.

53. Bogardus, S.T., Jr.; Holmboe, E.; Jekel, J.F. Perils, pitfalls, and possibilities in talking about medical risk. JAMA 1999, 281, 1037-1041. [CrossRef]

54. Blau, B.M.; Van Ness, R.A.; Wade, C. Capitalizing on catastrophe: Short selling insurance stocks around hurricanes Katrina and Rita. J. Risk Insur. 2008, 75, 967-996. [CrossRef]

55. Votsis, A.; Perrels, A. Housing prices and the public disclosure of flood risk: A difference-in-differences analysis in Finland. J. Real Estate Financ. Econ. 2016, 53, 450-471. [CrossRef]

56. Panduro, T.E.; Veie, K.L. Classification and valuation of urban green spaces-A hedonic house price valuation. Landsc. Urban Plan. 2013, 120, 119-128. [CrossRef]

57. Kuminoff, N.V.; Parmeter, C.F.; Pope, J.C. Which hedonic models can we trust to recover the marginal willingness to pay for environmental amenities? J. Environ. Econ. Manag. 2010, 60, 145-160. [CrossRef]

58. Charles, S. Housing Economics; Macmillan International Higher Education: London, UK, 2016.

59. Aye, G.C.; Balcilar, M.; Gupta, R. The Effectiveness Of Monetary Policy In South Africa Under Inflation Targeting: Evidence from a Time-Varying Factor-Augmented Vector Autoregressive Model. J. Dev. Areas 2020, 54. [CrossRef]

60. Ker, I.; Ginn, S. Myths and realities in walkable catchments: The case of walking and transit. Road Transp. Res. 2003, 12, 69.

61. Martínez, L.M.; Viegas, J.M. Effects of transportation accessibility on residential property values: Hedonic Price Model in the Lisbon, Portugal, metropolitan area. Transp. Res. Rec. 2009, 2115, 127-137. [CrossRef]

62. Chin, H.C.; Foong, K.W. Influence of school accessibility on housing values. J. Urban Plan. Dev. 2006, 132, 120-129. [CrossRef]

63. Owusu-Edusei, K.; Espey, M.; Lin, H. Does close count? School proximity, school quality, and residential property values. J. Agric. Appl. Econ. 2007, 39, 211-221. [CrossRef]

64. Belasen, A.R.; Polachek, S.W. How hurricanes affect wages and employment in local labor markets. Am. Econ. Rev. 2008, 98, 49-53. [CrossRef]

65. FEMA. Homeowner's Guide to Retrofitting; FEMA: Washington, DC, USA, 2009.

66. Rosenzweig, C.; Solecki, W.D.; Romero-Lankao, P.; Mehrotra, S.; Dhakal, S.; Ibrahim, S.A. Climate Change and Cities: Second Assessment Report of the Urban Climate Change Research Network; Cambridge University Press: Cambridge, UK, 2018.

67. Rosenthal, J.K.; Kinney, P.L.; Metzger, K.B. Intra-urban vulnerability to heat-related mortality in New York City, 1997-2006. Health Place 2014, 30, 45-60. [CrossRef] [PubMed]

68. Chambwera, M.A.; Heal, G.; Dubeux, C.; Hallegatte, S.; Leclerc, L.; Markandya, A.; McCarl, B.; Mechler, R.; Neumann, J. Economics of Adaptation. In Climate Change 2014; Impacts, Adaptation, and Vulnerability; Cambridge University Press: Cambridge, UK, 2014; pp. 945-977.

(C) 2020 by the author. Licensee MDPI, Basel, Switzerland. This article is an open access article distributed under the terms and conditions of the Creative Commons Attribution (CC BY) license (http://creativecommons.org/licenses/by/4.0/). 